\title{
Testicular Germ Cell Tumor
}

National Cancer Institute

\section{Source}

National Cancer Institute. Testicular Germ Cell Tumor. NCI Thesaurus. Code C8591.

A germ cell tumor arising from the testis. Representative examples include teratoma, seminoma, embryonal carcinoma, and yolk sac tumor. 